\title{
URBAN SPORTS SERVICE STRUCTURE FROM THE PUBLIC HEALTH CONTEXT
}

\author{
ESTRUTURA DE SERVIÇOS ESPORTIVOS URBANOS NO CONTEXTODA SAÚDE PÚBLICA
}

Rizhong Liang' (D)

(Sports Sociology)

1. School of Physical Education, Hechi University, Hechi, 546300, Guangxi, China.

\section{Correspondence:}

Hechi, 546300, Guangxi, China. vzedzr@163.com

\begin{abstract}
With the improvement of the quality of life, the residents' requirements for the construction of urban public sports services have gradually improved. In order to improve the current urban public sports service system, this study analyzes the existing public sports service through the construction of public sports service model. The results show that the current construction of public sports service has some defects, such as single construction subject, unbalanced regional development of sports service, lack of perfect performance evaluation mechanism of sports public service, and so on. Therefore, in the process of public sports service construction, we need to pay attention to the diversification of construction subjects, the cultivation of residents' awareness of physical exercise, the improvement of performance evaluation mechanisms of sports public services, and the broadening of investment channels. These measures can improve the urban public sports service system from the perspective of public health, and create better quality public sports services. This study analyzes the problems existing in the construction of public sports service by building a model, and puts forward some suggestions for improvement, hoping to provide ideas for scholars who study related experiments.
\end{abstract}

Keywords: Public sports service; model construction; construction strategy.

\section{RESUMO}

Com a melhoria da qualidade de vida, os requisitos da população para a construção de serviços desportivos públicos urbanos melhoraram gradualmente. A fim de melhorar o atual sistema de serviço público de esportes urbanos, este estudo analisa o serviço público de esportes existente através da construção do modelo de serviço público de esportes. Os resultados mostram que a atual construção do serviço público de esportes tem alguns defeitos, como a questão da construção única, o desenvolvimento regional desequilibrado dos serviços de esportes, a falta de um mecanismo perfeito de avaliação do desempenho do serviço público de esportes e assim por diante. Por conseguinte, no processo de construção desses serviços, temos de prestar atenção à diversificação das disciplinas de construção, à cultura da conscientização da população para o exercício físico, à melhoria do mecanismo de avaliação do desempenho do serviço público de esportes e à expansão dos canais de investimento. Essas medidas podem melhorar o sistema de serviços públicos urbanos de esportes do ponto de vista da saúde pública e criar serviços desportivos públicos de maior qualidade. Este estudo analisa os problemas existentes na construção desses serviços através da construção de um modelo, e apresenta algumas sugestões para melhorias, esperando fornecer ideias para pesquisadores que estudam experimentos relacionados.

Descritores: Serviço desportivo público; construção de modelos; estratégia de construção.

\section{RESUMEN}

Con la mejora de la calidad de vida, se han ido mejorando paulatinamente las exigencias de la población para la construcción de servicios deportivos públicos urbanos. Con el fin de mejorar el actual sistema de servicios públicos deportivos urbanos, este estudio analiza el servicio público deportivo existente mediante la construcción de un modelo de servicio público deportivo. Los resultados muestran que la construcción actual del servicio público deportivo tiene algunos defectos, como el tema de construcción única, el desarrollo regional desequilibrado del servicio deportivo, la falta de un perfecto mecanismo de evaluación del desempeño del servicio público deportivo, etc. Por ello, en el proceso de construcción de los servicios públicos deportivos, es necesario prestar atención a la diversificación de los temas de construcción, el cultivo de la conciencia de la población sobre el ejercicio físico, la mejora de los mecanismos de evaluación del desempeño de los servicios públicos deportivos y la ampliación de los canales de inversión. Estas medidas pueden mejorar el sistema de servicios deportivos públicos urbanos desde la perspectiva de la salud pública y crear servicios deportivos públicos de mayor calidad. Este estudio analiza la problemática existente en la construcción del servicio público deportivo mediante la construcción de un modelo, y presenta algunas sugerencias de mejora, esperando brindar ideas para los académicos que estudian experimentos relacionados.

Descriptores: Servicio público de deportes; modelización; estrategia de construcción. 


\section{INTRODUCTION}

Under the background of public health, how to build a perfect public sports service system has become an urgent problem. Because the understanding of public sports service in China is not deep enough, the relevant theoretical research on public sports service is not mature enough. The research on public sports service is mostly discussed from the perspective of concept, which may deviate from the actual situation. The construction of a public sports service model can provide a more realistic theoretical basis platform for the research and analysis of public sports service. Based on this reason, this study will build a public sports service model through the soft thinking method, analyze the shortcomings in the construction of public sports service in reality, and put forward some targeted suggestions to help build a more perfect sports public service system.

Song $\mathrm{Ci}$ et al. predicted the exercise intention of adults through the theory of planned behavior, and found that the exercise intention of adults would be affected by other people, and the exercise intention would be enhanced.' Scholar Banda d found that sports has a very important contribution to international development, but sports institutions lack participation in strategic decision-making and are marginalized by other departments. There are significant differences in the implementation of sports in different countries. ${ }^{2} \mathrm{CAl}$ and other researchers in the study of rural sports public services, starting from the investment and current situation analysis, using the trend extrapolation prediction model and statistical analysis method to study the rural sports. The results show that there are some problems in rural sports in China, such as low investment, weak awareness of sports, imperfect use of sports facilities, imperfect stadium construction, sports management system is not perfect The maintenance of sports facilities is not standardized. ${ }^{3}$ Garcia unanue and other scholars use cost accounting tools to manage public sports service departments, so as to improve and update the financial management of public sports services. ${ }^{4}$ Scholars Pengyu $R$ and Zhao oxia analyzed the problems of insufficient number, unbalanced layout and poor management of sports facilities in urban residential areas in China through literature and survey methods, and proposed to formulate sports facilities planning policies and update existing sports facilities to solve such problems. ${ }^{5}$ Xujin et al. through the survey of satisfaction of urban and rural residents on community experience, they found that there was a significant difference between urban and rural residents' satisfaction with community sports.

Through the research of different students at home and abroad, we can find that nowadays the society attaches great importance to public sports service and public health. The number and types of research on the two are rich, but the related research on public sports service system is not mature. Therefore, this study is related to the construction of public sports service from the perspective of public health. Through the construction of public sports service model, this paper analyzes the shortcomings of public sports service system, and puts forward corresponding improvement suggestions, so as to promote the improvement of public sports service construction.

\section{Public sports service construction}

Through the model of public sports service, this paper makes a detailed analysis and Research on the construction of public sports service in s city. It needs to follow the four principles of public service system, namely, the principle of common enjoyment, the principle of equality and equality, the principle of efficiency and performance, and the principle of convenience This paper analyzes the situation of urban public sports services from the following aspects: the situation, the situation of sports associations and members, the situation of system detection and residents' satisfaction, the current situation of sports funds supply.

Table 1 (a) shows the completion rate of "10 minutes sports fitness circle" in S City in 2012. It can be seen that the completion rate of 10 districts in s city is high, of which the completion rate of GS area is 100\%, and that of TC area is only 89\%. Combining the investigation of residents' choice of sports fitness places with the consideration of sports fitness circle, it can be found that residents prefer more convenient venues. Therefore, in the establishment of sports facilities, we should consider the convenience factor, narrow the scope of stadiums and residential areas, so as to improve the enthusiasm of residents for physical exercise and the utilization rate of sports facilities. Table 1 (b) shows the situation of sports associations in s city. There are 156 associations in S City, including 31 municipal associations and 28 municipal clubs.

From Table 2, we can see the total number of club members and the new number of S City in 2010, 2011 and 2012. In 2010, the total number of sports club members in s city was 135723, including 35243 municipal sports associations and 48346 municipal sports clubs; in 2011, the total number of new members in s city was 249365, including 16088 and 7676 new members of municipal sports associations and municipal sports clubs; in 2012, the total number of new members in s city was 556346, including municipal sports clubs The number of new league and municipal sports clubs increased by 22994 and 1488 respectively. S city has a registered population of 6.478 million and a permanent resident population of 10.466 million. It can be seen that the total number of community members in $\mathrm{s}$ city is relatively small, but the number of members has increased rapidly in recent two years. It shows that these areas have a great demand for sports activities and guidance; for areas with relatively weak economic conditions, we can see that the number of members is limited, which shows that the construction of public sports services in s city presents an unbalanced trend. We can establish a scientific and reasonable sports resource allocation mechanism to allocate resources, so as to reduce the existing public sports service construction in various regions Imbalance.

It can be seen from Table 3 (a) that the satisfaction degree of each district of s city to the construction of public sports service is quite different. The highest satisfaction can reach $97.5 \%$, and the lowest is only 53.8\%. This shows that the degree of public sports service construction in different districts is different. Table 3 (b) shows residents' satisfaction

Table 1. Sports development in different regions of S City.

\begin{tabular}{c|c|c|c}
\hline \multicolumn{2}{c|}{$\begin{array}{c}\text { (a) Completion rate of "10 minute } \\
\text { sports fitness circle" in S City in } \mathbf{2 0 1 2}\end{array}$} & \multicolumn{2}{c}{ (b) Sports associations in S City } \\
\hline Company & Completion rate & Company & Number of associations \\
\hline ZJ & $90 \%$ & ZJ & 17 \\
\hline CS & $91 \%$ & CS & 17 \\
\hline TC & $89 \%$ & TC & 15 \\
\hline KS & $96 \%$ & KS & 14 \\
\hline WJ & $92 \%$ & WJ & 20 \\
\hline WZ & $93 \%$ & WZ & 12 \\
\hline XC & $98 \%$ & XC & 1 \\
\hline GS & $100 \%$ & JL & 1 \\
\hline Y & $98 \%$ & Municipal Club & 28 \\
\hline GX & $90 \%$ & $\begin{array}{c}\text { Municipal } \\
\text { associations }\end{array}$ & 31 \\
\hline
\end{tabular}

Table 2. Statistics of sports clubs in S City.

\begin{tabular}{c|c|c}
\hline Company & $\begin{array}{c}\text { Municipal Sports } \\
\text { Associations }\end{array}$ & Municipal Sports Club \\
\hline 2010 Number of members & 35243 & 48346 \\
\hline New members in 2011 & 16088 & 7676 \\
\hline New members in 2012 & 22994 & 14688 \\
\hline
\end{tabular}


with public sports service facilities in s city. Among them, $88.3 \%$ are satisfied with street and community sports color donation facilities, 82\% are satisfied with large-scale comprehensive sports facilities, $77.7 \%$ and $68.5 \%$ are satisfied with the opening of operating fitness venues and school sports facilities to residents. Through the investigation of public sports facilities in S City, it is found that the public sports resources are still insufficient. We should expand the supply channels of public goods by increasing the financial revenue, and then improve the investment of public sports resources. It is an important means to supervise and assess the government and its behavior. A sound social supervision mechanism can form public opinion supervision on public sports service and solve the problems in the construction of service system in time; increase the government's work in mass sports construction, increase the input of sports products and services; broaden the evaluation subject of sports public service system; and improve the sports public service system.

Table 4 shows the status of sports instructors in s city. It can be seen that there are 91 national sports instructors, 577 provincial level sports instructors, 6164 provincial level instructors and 14838 provincial level instructors, which means that there are 21670 sports instructors in s city. There are 67.21 sports instructors per 10000 registered population in each district, and the lowest is 5.28; the highest number of sports instructors is 32.73 and the lowest is 3.18 . Both of them have the lowest number of sports instructors per 10000 people in the same district, but the districts with the highest number of sports instructors per 10000 people are different, which indicates that the floating population of s city is large. Therefore, in the construction of public sports service in S City, a group of professional sports instructors can be employed to guide and publicize sports knowledge in places with a large number of people; free teaching of sports should be set up; publicity groups should be set up to regularly carry out sports propaganda and guidance; sports director associations should be established to standardize the duties and behaviors of instructors; and the association regulations should be formulated to protect the rights and interests of sports instructors. On the one hand, the sports instructor association belongs to the government's measures to promote the construction of public sports service,

Table 3. Investigation on satisfaction of sports public service.

\begin{tabular}{c|c|c|c|c|c}
\hline \multicolumn{6}{c}{ (a) Survey on satisfaction of public sports service in S City } \\
\hline Satisfaction & $89.5 \%$ & $91.3 \%$ & $53.8 \%$ & $97.5 \%$ & $95.8 \%$ \\
\hline \multicolumn{6}{c}{ (b) Satisfaction survey of public sports facilities in S City } \\
\hline & $\begin{array}{c}\text { Street and } \\
\text { community } \\
\text { sports lottery } \\
\text { donation facilities }\end{array}$ & $\begin{array}{c}\text { Large scale } \\
\text { comprehensive } \\
\text { sports facilities }\end{array}$ & $\begin{array}{c}\text { Commercial } \\
\text { fitness } \\
\text { venues }\end{array}$ & $\begin{array}{c}\text { Opening of } \\
\text { school sports } \\
\text { facilities to } \\
\text { residents }\end{array}$ \\
\hline Satisfaction & $88.3 \%$ & $82 \%$ & Wu Dhong & Xiangcheng \\
\hline
\end{tabular}

Table 4. Status of sports instructors in S City.

\begin{tabular}{c|c|c|c|c|c|c}
\hline Region & $\begin{array}{c}\text { National } \\
\text { level }\end{array}$ & $\begin{array}{c}\text { Provincial } \\
\text { level 1 }\end{array}$ & $\begin{array}{c}\text { Provincial } \\
\text { level 2 }\end{array}$ & $\begin{array}{c}\text { Provincial } \\
\text { level 3 }\end{array}$ & $\begin{array}{c}\text { Number of } \\
\text { registered } \\
\text { population } \\
\text { per 10000 }\end{array}$ & $\begin{array}{c}\text { Number of } \\
\text { permanent } \\
\text { residents per } \\
\mathbf{1 0 0 0 0} \text { people }\end{array}$ \\
\hline ZJ & 17 & 190 & 1142 & 2736 & 44.89 & 32.73 \\
\hline CS & 10 & 113 & 680 & 1560 & 22.13 & 15.65 \\
\hline TC & 6 & 32 & 376 & 794 & 25.54 & 16.97 \\
\hline KS & 5 & 91 & 1819 & 3045 & 67.21 & 30.13 \\
\hline WJ & 7 & 42 & 719 & 1594 & 29.34 & 18.53 \\
\hline WZ & 3 & 46 & 288 & 773 & 18.23 & 9.59 \\
\hline XC & 3 & 15 & 593 & 1143 & 45.37 & 25.3 \\
\hline GS & 5 & 43 & 263 & 1857 & 29.2 & 23.02 \\
\hline GY & 33 & 4 & 183 & 1256 & 37.03 & 20.83 \\
\hline GX & 5 & 1 & 101 & 80 & 5.28 & 3.18 \\
\hline Total & 91 & 577 & 6164 & 14838 & 33.45 & 20.71 \\
\hline
\end{tabular}

on the other hand, it guides residents to accept appropriate physical exercise and training, which can effectively promote the improvement of public sports service construction.

\section{CONCLUSIONS}

Physical exercise has been thoroughly integrated into the daily life of residents. An efficient public sports service system can promote the development of sports and meet the sports needs of residents. This study analyzes the construction of public sports service through the construction of public sports service model. The results show that there are some problems in the current public sports service, such as unbalanced sports construction, single construction subject, insufficient resource investment, insufficient awareness of physical exercise of residents, and lack of performance evaluation system of sports public service. Therefore, in the construction of public sports service, in order to solve the problem of single construction subject, the government should play a leading role, pay attention to the real needs of residents, form a multi participation service system, establish and improve the performance evaluation mechanism of sports public service, plan the government and its behavior, ensure the sustainable construction of sports public service, broaden the channels of capital investment, and carry out the sports public service construction. We should educate and publicize, improve the residents'consciousness of physical exercise, and make rational use of the market. Through the above methods, we can gradually improve the construction of public sports service. It is hoped that with the in-depth investigation of public sports service, a more scientific and perfect public sports service system can be built in the future.

The author declare no potential conflict of interest related to this article

AUTHORS' CONTRIBUTIONS: The author has completed the writing of the article or critical comments on its knowledge content. This paper can be used as the final manuscript. Every author has made an important contribution to this manuscript. Rizhong Liang: write and execute.

\section{REFERENCES}

1. Song C I, Park H S. Testing Intention to Continue Exercising at Fitness and Sports Centers with the Theory of Planned Behavior. Social Behavior and Personality: an international journal. 2015; 43(4):641-648

2. Banda D. Sport for Development and Global Public Health Issues A Case Study of National Sports Associations. Aims Public Health. 2017; 4(3):240-257.

3. Cai H, Wang Y. Chinese Rural Sports Public Service Funds Input Current Status Analysis and Prediction.
Open Cybernetics \& Systemics Journal. 2015; 9(1):1646-1652

4. García-Unanue J, Felipe JL, Gallardo, L. Using Action Research to Achieve the Implementation of Cost Accounting: The Case of the Public Sports Organizations at Local Level. Systemic Practice \& Action Research. 2015; 28(2):111-123.

5. Pengyu R, Zhaoxia L. Planning and construction of sports facilities in urban residential areas in China. Open House International. 2017; 42(3):120-124. 